\title{
Evaluare și intervenție logopedică în contextul întârzierii în dezvoltarea Iimbajului
}

\section{Florentina Mihaela MOȘNEAG ${ }^{1}$}

\begin{abstract}
According to the literature, we are talking about a language delay when the child fails to reach the level of language evolution, compared to his chronological age. In fact, we know that language development is closely linked to cognitive development. Therefore, the structure of language is influenced by the degree of cognitive development. Knowing that the language delay may exists as a secondary pathology in most intellectual disabilities and can be recognized by the poverty of vocabulary, the inability to express themselves correctly in sentences or phrases, being reached phonetic, lexical and grammatical aspects, I wanted to surprise in this study the features of language development in young children oriented towards our school by proposing a complex, multidimensional approach to early assessment of language skills and capturing the effect of a multidimensional intervention program that will ultimately lead to the configuration of functional communication skills. Children included in this study are enrolled in the kindergarten group or in the preparatory class, aged between 4 and 8 years. These children are also diagnosed with mild or moderate intellectual disability.

The program took place in two stages. In the first stage, a multidimensional evaluation was performed, on all sides of the language by applying tests, scales or evaluation tests. The results obtained by the children were interpreted and presented at the level of some case studies. In the second stage, we proposed an intervention program that aims to enrich and activate vocabulary, by applying the "50 word-list technique$T^{50 "}$, training phonetic and phonological skills, those related to structural semantics and lexical semantics and shaping morphological skills, which will lead to the configuration of a functional communication skill related to chronological and mental age.
\end{abstract}

Keywords: language delay, communication skills, early assessment of language skills, multidimensional intervention program.

\section{Introducere}

Limbajul este o componentă proprie creierului uman, datorită utilizării în timpul producerii lui a unui sistem arbitrar de semne: limba, de natura fie sonoră, fie vizuală. Născut din nevoia de comunicare cu aproapele, limbajul înseamnă folosirea unui cod, dar cu particularitățile individuale, în cadrul aceluiași grup social. Deși folosește același cod, adică limba, limbajul reprezintă folosirea limbii la nivel individual; în acest sens, limba poate fi considerată un instrument, pe care fiecare persoană îl folosește când vrea, când poate, dar mai ales cum poate, având $\quad \mathrm{o}$ funcționare condiționată multifactorial (Burlea, 2007).
Vorbim de întârziere în dezvoltarea limbajului atunci când copilul nu reușește să atingă nivelul de evoluție al limbajului, raportat la vârsta cronologică. De obicei, această întârziere există ca fenomene secundare în mai toate dizabilitățile de intelect și senzoriale dar se pot manifesta și de sine stătător.

Întârzierea în dezvoltarea limbajului se recunoaște după sărăcia vocabularului și după neputința de a se exprima corect, logic în propoziții și fraze. Frecvent, întârzierile de dezvoltare a limbajului cuprind atât aspectele fonetice, lexicale, cât și gramaticale. Datorită acestor fenomene, și înțelegerea vorbirii 
celor din jur se realizează cu dificultate, ceea ce înfluențează negativ evoluția psihică generală și comportamentală. Asemenea întârzieri pot fi determinate de carențele sistemului nervos central provocate de hemoragii cerebrale în timpul nașterii, de eventuale boli grave, de lipsa de stimulare a comunicării în perioada primei copilării (Avramescu, 2007).

Psihologi de prestigiu subliniază relaţia dintre dezvoltarea intelectuală şi dezvoltarea limbajului. Dezvoltarea limbajului în general, este tributară dezvoltării intelectuale. Pentru a învăţa să vorbești, trebuie să poți înțelege (Delacroix). Din acest punct de vedere, cercetările lui Vâgotski, care consideră limbajul ca instrument al dezvoltării mentale, şi ale lui Luria şi Kendler, în concepţia cărora limbajul joacă rolul de reglator al comportamentului şi al activităţii voluntare, stabilesc semnificaţia limbajului pentru dezvoltarea psihicului, în general, şi a gândirii conceptualizate, în special. La copiii cu dizabiliate intelectuală, structura limbajului este influențată de gradul acesteia, deoarece utilizarea cuvintelor, a propoziţiilor, a frazelor şi a înţelegerii semnificației lor depind de capacitatea de asimilare a gândirii (Tatiana Slama-Cazacu, 1999) şi mai puţin de nevoile și interesele copilului.

Toate aspectele evidenţiate cu privire la întârzierea în dezvoltarea limbajului şi al relaţiei acestuia cu disfazia se regăsesc şi în cazurile de dizabilitate intelectuală, cu o simptomatologie generată de vidul mental şi de etiologia determinantă care a influenţat structurile neuropsihice în condiţiile date. La aceste caracteristici se adaugă şi o fenomenologie rezultată din particularităţile de structură anatomică şi psihică, specifică dizabilității respective. Formele cele mai accentuate ale tulburărilor de limbaj se întâlnesc în dizabilitatea intelectuală, şi cum aceasta are grade diferite, de la uşor la sever şi profund, dificultăţile de limbaj se prezintă pe o ierarhie foarte diversă și complexă. Întârzierea în dezvoltarea limbajului ocupă un loc central pe această scară și are implicații extinse, atât în desfaşurarea activităţii psihice generale, cât şi a comportamentelor adaptative (Preda, 2007).

Datorită varietății dificultăților din cadrul diagnosticului, dezvoltarea vorbirii și intervenția în întârzierea de dezvoltare a limbajului pot lua multe forme. Law et al. (200o) definesc abordările intervenției folosind trei categorii: didactice (instruire directă a comportamentelor lingvistice), naturaliste (învățarea copilului să răspundă eficient la cerințele lingvistice ale mediului) și hibride (o combinație între didactic și naturalist). Acești termeni oferă un cadru util pentru a contura abordări ale intervenției, deși, un terapeut poate folosi o abordare eclectică și poate adapta intervențiile în funcție de răspunsul clientului (Law, J., Garrett, Z., Nye, C. , 2005)

Demersul de intervenție în contextul întârzierii în dezvoltarea limbajului poate fi nuanțat în funcție de următorii parametrii (Bodea Hațegan, 2016):

-Vârsta cronologică la care s-a realizat diagnosticarea;

-Factorii de mediu care interferează cu evoluția tipică;

-Specificitatea simptomatologică; 
- Severitatea

tabloului

simptomatologic;

- Tehnica listei celor 50 de cuvinte - $\mathrm{T}^{50}$

În programul terapeutic abordat în problematica dezvoltării limbajului a fost folosită o tehnică terapeutică specifică elaborată de Carolina Bodea Hațegan Tehnica listei celor 50 de cuvinte - $\mathrm{T}^{50}$. Această tehnică a fost implementată la nivelul unor studii de caz, în mod empiric. Ea a fost elaborată și experimentată ca urmare a concluziilor subliniate de Petionou, Spanoudis (2014, apud Bodea Hațegan, 2016) cu privire la întârzierea în dezvoltarea limbajului. Aceștia subliniază faptul că, de obicei, diagnosticul de întârziere în dezvoltarea limbajului se stabilește atunci când copilul are un ritm încetinit de achiziție a limbajului, apar discrepanțe între dezvoltarea abilităților lingvistice și vârsta cronologică a copilului, iar în aceste condiții volumul vocabularului este redus, de obicei, la mai puțin de 50 de cuvinte.

Această tehnică presupune întocmirea unei liste de cuvinte ce urmează a fi învățate, reactualizarea cuvintelor de către copil după modelul terapeutului, modelarea pronunției cuvintelor de către terapeut, generalizarea utilizării cuvintelor de către părinte în mediul familial, prin abordarea naturală a conversației.

Lista trebuie să conțină cuvinte simple din punct de vedere fonetic, care nu ridică dificultăți articulatorii majore, cuvinte care odată însușite facilitează și inserția copilului în grupul de prieteni, colegi, facilitează stabilirea de relații comunicaționale adecvate cu părinții.
Este recomandat ca $\mathrm{T}^{50}$ să fie implementată până în momentul în care copilul reușește să pronunțe corect cele 50 de cuvinte din listă. Se poate realiza și un profil de achiziție a cuvintelor, iar cuvintele pe care copilul le poate pronunța corect sau care sunt în curs de modelare trebuie prezentate și părintelui pentru ca acesta, în mediul familiar, să asigure generalizarea utilizării lor corecte (Bodea Hațegan, 2016).

\section{Metodologia cercetării}

\section{Oijiectivele cercetărī}

Evidențierea

particularităților de dezvoltare a limbajului la copiii de vârsta mică cu dizabilitate intelectuală;

Propunerea unui demers complex, multidimensionat (pe toate laturile limbajului) pentru evaluarea timpurie a abilităților lingvistice;

Surprinderea efectului unui program de intervenție multidimensionat;

\section{Ipoteze}

Există o relație între utilizarea $T^{50}$ și dezvoltarea abilităților lexico-semantice;

Există relații între dezvoltarea abilităților lexico-semantice și conturarea morfologică în contextul întârzierii în dezvoltare;

Programul de intervenție multidimensionat conduce la configurarea unei competențe de comunicare funcționale;

\section{Prezentarea lotului de suliecti}

În prezentul studiu au fost incluși un număr de 5 copii ( 2 băieți și 3 fete) care prezintă semne ale întârzierii în dezvoltarea limbajului. Aceștia provin din grupele de grădiniță și clasa 
pregătitoare ai Centrului Școlar pentru Educație Incluzivă „,Speranța”, Zalău și prezintă, conform certificatului de orientare școlară și profesională, întârzieri ușoare și medii în dezvoltarea intelectuală. Prezentul studiu s-a desfășurat în perioada septembrie 2019august 2020.

\section{Descrierea înstrumentarului utilizat}

Pentru evaluarea copiilor au fost utilizate metode variate incluzând observarea lor în diverse medii, anamneza, intervievarea celor care cunosc copilul dar și probe, scale și teste standardizate:

-Scala de Dezvoltare Portage- este un test de evaluare a copiilor mici (cu vârste de până la 6 ani)

-Scala integrată de dezvoltare - acest instrument a fost tradus și adaptat pentru pentru limba română în anul 2012 sub coordonarea lui Anca și Bodea Hațegan și este o scală care redă abilități din următoarele domenii: ascultarea/audiția, limbajul receptiv, limbajul expresiv, vorbirea, cogniţia, comunicarea.

-Proba pentru cunoașterea vârstei psihologice a limbajului adaptată după Alice Descoeudres - cuprinde 7 probe, fiecare stabilind o anumită vârstă a limbajului pentru aspectul pe care îl vizează.

-Scala pentru stabilirea nivelul de dezvoltare a limbajului - Scala permite stabilirea corectă a diagnosticului de întârziere în apariția și dezvoltarea limbajului.

- „Pași prin lumea sunetelor”- Aplicația "Pași prin lumea sunetelor!" este un instrument elaborat de Carolina Bodea - Hațegan și Dorina Talaș, cu sprijinul Cochlear România și al ASTTLR.

-Probă de evaluare a abilităților morfologice în limba română - Proba a fost elaborată de către Carolina Bodea-Haţegan în anul 2014 în vederea evaluării laturii morfologice a limbajului.

\section{Procedura de Iucru}

Programul s-a desfășurat în două etape: evaluare inițială, în care au fost surprinse particularitățile de dezvoltare a limbajului la copiii de vârstă mică cu dizabilități intelectuale ușoare și moderate și a doua etapă de implementare a unui program de intervenție multidimensionat la copii evaluați și surprinderea efectului programului propus. Frecvența întâlnirilor în cadrul ședințelor de terapie a fost de una sau două pe săptămână cu o durată de aproximativ 40 de minute.

În prima etapă, a evaluării, au fost aplicate probele, testele și scalele prezentate anterior. Acestea au fost aplicate individual, în medii adecvate, timpul de administrare variind de la caz la caz. De asemenea au fost culese date din interviurile cu părinții, cadrele didactice de la clasă sau din echipa multidisciplinară și din documentele medicale ale fiecărui copil.

În cadrul celei de-a doua etape, s-a elaborat și implementat programul de intervenție. În implementarea programului s-a utilizat Tehnica listei celor 50 de cuvinte $-\mathrm{T}^{50}$. Activitățile specifice acestei tehnici au fost introduse la începutul ședințelor terapeutice, urmând ca la fiecare nouă ședință să se recapituleze cuvintele învățate anterior. 
Copiilor le-au fost prezentate cuvintele care urmează să fie învățate, aceștia având sarcina de a reproduce cuvântul auzit. În cazul în care pronunția era defectuoasă s-a încercat corectarea acesteia fără însă a insista, conform recomandărilor $\mathrm{T}^{50}$. Listele de cuvinte au fost abordate fragmentat în funcție de potențialul și evoluția fiecărui copil. A avut loc o notare ritmică a cuvintelor însușite. După această etapă a ședinței sa recurs la un set de exerciții pentru dezvoltarea conștiinței fonologice care cuprinde o parte din cuvintele aflate în liste. Exercițiile desfășurate în vederea dezvoltării conștiinței fonologice au fost adaptate după un set de itemi care testau abilitățile lingvistice ale elevilor preșcolari din Norvegia în cadrul unui studiu desfașurat de S.A.H. Lyster, A. O. Lerva, și C. Hulme (2016). Cuvintele și imaginile au fost atent alese astfel încât unele se regăsesc printre cuvintele incluse în Lista celor 50 de cuvinte, pentru a facilita înțelegerea acestora, iar pentru altele criteriile de selecție au fost: să fie ușor de recunoscut și să nu creeze dificultăți articulatorii majore, cuvinte accesibile copiilor din punct de vedere al pronunţiei, şi utile din punct de vedere al experienței și practicii educaționale.

Activitățile desfășurate pentru dezvoltarea conștiinței fonologice au implicat activități de identificare a fonemelor, de cobinare a fonemelor, identificarea unei imaginii când sunt date sunetele corespunzătoare, exerciții de numărare a fonemelor și eliminarea fonemelor inițiale, exerciții de despărțire în silabe, cu numărarea acestora, exerciții de combinare a cuvintelor în propoziție. $\mathrm{Au}$ fost introduse în această etapă și activități specifice pentru formarea abilităților de sesizare a rimei.

Exercițiile, privind dezvoltarea competențelor morfologice, au fost alese și implementate ca urmare a rezultatelor copiilor obținute la "Proba de Evaluare a Abilităţilor Morfologice în Limba Română. Aplicaţii psiholingvistice" (PEAMLR). În alegerea materialului lingvistic s-a urmărit introducerea cuvintelor nou învățate. Au fost folosite imagini însoțite de cerința de a identifica imaginea corespunzătoare enunțului, cum ar fi: ,Leul este in cușcă.”; „În coș sunt mere.” ; ,Trei copii se joacă.”, ,, Al treilea balon este albastru.", Ei aleargă.; , Ochelarii sunt pe carte." De asemenea au fost desfășurate jocuri de genul ,, Eu spun una, tu spui mai multe", găsirea unui adjectiv potrivit pentru un substantiv sau verb dat, exerciții cu prepoziții simple și compuse, exerciții pentru însușirea conceptului de numerație și de recunoaștere a numeralelor ordinale. Demersul terapeutic a avut la bază obiectivele propuse.

\section{Evaluarea innitială}

În urma evaluărilor se observăm că cei 5 copii incluși în prezentul studiu prezintă întârziere în dezvoltarea limbajului pe fondul unei dizabilități intelectuale ușoare sau medii. Pe lângă întârzierea în dezvoltarea intelectuală copiii mai prezintă tulburări emoționale, întârziere psihomotrică, tulburări de conduită și deficit atențional iar , o parte din ei, provin dintr-un mediu policarențat. Toate aceste tablouri pot fi cauze ale întârzierii în dezvoltarea limbajului sau, cu alte cuvinte, întârzierea în dezvoltarea limbajului poate apărea pe un fond patologic. 


\begin{tabular}{|c|c|c|c|c|c|c|}
\hline $\begin{array}{l}\text { Nr. } \\
\text { crt. }\end{array}$ & $\begin{array}{l}\text { Nume și } \\
\text { prenume }\end{array}$ & $\begin{array}{l}\text { Încadrarea diagnostică } \\
\text { ( conform Certificatului de } \\
\text { orientare școlară și } \\
\text { profesională) }\end{array}$ & Sex & $\begin{array}{l}\text { Vârsta } \\
\text { cronologică }\end{array}$ & $\begin{array}{l}\text { Vârsta } \\
\text { mentală } \\
\text { (conform } \\
\text { Scalei } \\
\text { Portage) }\end{array}$ & $\begin{array}{l}\text { IQ } \\
\text { (conform } \\
\text { Scalei } \\
\text { Portage) }\end{array}$ \\
\hline 1. & B.A.A. & $\begin{array}{l}\text { Tulburare de dezvoltare } \\
\text { intelectuală-retard psihic ușor, } \\
\text { deficit atențional, tulburări } \\
\text { emoționale, tulburare de } \\
\text { atașament, mediu policarențat }\end{array}$ & $\mathrm{F}$ & 8 ani & $\begin{array}{l}4 \text { ani și } 7 \\
\text { luni }\end{array}$ & 52 \\
\hline 2. & V.L. & $\begin{array}{l}\text { Retard psihic ușor, tulburări de } \\
\text { conduită și emoționale }\end{array}$ & $\mathrm{F}$ & $\begin{array}{l}7 \text { ani și } 10 \\
\text { luni }\end{array}$ & 5 ani & 64 \\
\hline 3. & L.A. & $\begin{array}{l}\text { Retard psihic ușor, sindrom } \\
\text { hiperkinetic, întârziere } \\
\text { psihomotrică }\end{array}$ & $\mathrm{M}$ & 4 ani și 5 luni & $\begin{array}{l}2 \text { ani și } 10 \\
\text { luni }\end{array}$ & 64 \\
\hline 4. & B.B.I. & $\begin{array}{l}\text { Tuburări emoționale, crize de } \\
\text { afect, intelect de limtă, } \\
\text { substimulare }\end{array}$ & $\mathrm{M}$ & 5 ani și 3 luni & $\begin{array}{l}4 \text { ani și } 1 \\
\text { lună }\end{array}$ & 78 \\
\hline 5. & V.R. & $\begin{array}{l}\text { Retard psihic mediu, sindrom } \\
\text { hiperkinetic, crize de afect, } \\
\text { dificultăți de învățare }\end{array}$ & $\mathrm{F}$ & 7 ani și 2 luni & $\begin{array}{l}4 \text { ani și } 8 \\
\text { luni }\end{array}$ & 65 \\
\hline
\end{tabular}

Tab. 1 Tabel cu datele elevilor incluși în program

Privind la Rezultatele obținute la Probele pentru cunoașterea vârstei psihologice a limbajului se observă că patru din cei cinci copii au o vârstă psihologică a limbajului sub 4 ani în timp ce unul dintre copii are o vârstă psihologică de 1 an și 10 luni. Există diferențe în ce privește vârsta cronologică și vârsta psihologică a limbajului și, comparând datele de mai sus se poate concluziona că există diferențe inclusiv între vârsta mentală și vârsta psihologică a limbajului.

Probelor pentru cunoașterea vârstei psihologice a limbajului( A. Descouders)

\begin{tabular}{llll}
\hline \hline $\begin{array}{l}\text { Nr. } \\
\text { crt. }\end{array}$ & $\begin{array}{l}\text { Nume și } \\
\text { prenume }\end{array}$ & $\begin{array}{l}\text { Vârsta } \\
\text { cronologică }\end{array}$ & $\begin{array}{l}\text { Vârsta } \\
\text { psihologică } \\
\text { de } \\
\text { dezvoltare } \\
\text { a limbajului }\end{array}$ \\
\hline \hline 1. & B.A.A. & 8 ani & $\begin{array}{l}\text { 3 ani și 6 } \\
\text { luni }\end{array}$ \\
\hline 2. & V.L. & $\begin{array}{l}7 \text { ani și 10 } \\
\text { luni }\end{array}$ & $\begin{array}{l}\text { 3 ani și 11 } \\
\text { luni }\end{array}$ \\
\hline 3. & L.A. & $\begin{array}{l}\text { 4 ani și } 5 \\
\text { luni }\end{array}$ & $\begin{array}{l}\text { 1 an și 10 } \\
\text { luni }\end{array}$ \\
\hline 4. & B.B.I. & $\begin{array}{l}5 \text { ani și 3 } \\
\text { luni }\end{array}$ & $\begin{array}{l}\text { 3 ani și 2 } \\
\text { luni }\end{array}$ \\
\hline 5. & V.R. & $\begin{array}{l}7 \text { ani și 2 } \\
\text { luni }\end{array}$ & $\begin{array}{l}\text { 3 ani și 2 } \\
\text { luni }\end{array}$ \\
\hline \hline
\end{tabular}

Tab.2 Tabel cu Vârsta psihologică a limbajului obținută în urma aplicării

Evaluare competențelor morfologice s-a realizat prin "Proba de Evaluare a Abilităților Morfologice în Limba Română. Aplicaţii psiholingvistice" (PEAMLR). În următorul tabel putem observa rezultatele obținute de copii la această probă.

\begin{tabular}{llll}
\hline Nr.crt. & $\begin{array}{l}\text { Nume și } \\
\text { prenume }\end{array}$ & IQ & $\begin{array}{l}\text { Rezulate } \\
\text { obținute la } \\
\text { PEAMLR }\end{array}$ \\
\hline \hline $\mathbf{1 .}$ & B.A.A. & 52 & 46 \\
\hline 2. & V.L. & 64 & 39 \\
\hline 3. & L.A. & 64 & 36 \\
\hline 4. & B.B.I. & 78 & 43 \\
\hline
\end{tabular}




\begin{tabular}{cccc}
\hline \hline 5. & V.R. & 65 & 45 \\
\hline \multicolumn{4}{c}{ Tab 3} \\
Rezultate obținute de copii la \\
PEAMLR
\end{tabular}

Comparând rezultatele obținute de copii cu etalonul orientativ observăm că unul dintre aceștia se încadrează în intervalul de percentile $5-8$, iar 4 obțin rezultate care se încadrează în intervalul de percentile 3-6. Aceste rezultate sunt influențate nu doar de capacitatea intelectuală a copilului sau de gradul de dizabilitate intelectuală ci și de volumul vocabularul de care dispune copilul, nivelul lexical și capacitatea de comprehensiune verbală.

Implementarea și surprinderea efectului programului de intervenție multidimensionat

Pentru a surprinde evoluția și nivelul de achiziție a cuvintelor propuse pentru $\mathrm{T}^{50}$, s-a întocmit pentru fiecare copil câte un tabel privind profilul de achiziție a cuvintelor (Tab.4). Cuvintele care au fost pronunțate corect, sau au fost în curs de modelare, au fost prezentate părinților și cadrelor didactice de la clasă pentru ca să se extindă utilizarea lor corectă și în alte medii decât cabinetul.

\begin{tabular}{|c|c|c|c|c|}
\hline $\begin{array}{l}\text { Nr. } \\
\text { crt. }\end{array}$ & $\begin{array}{l}\text { Cuvinte } \\
\text { nou } \\
\text { abordate }\end{array}$ & $\begin{array}{l}\text { Cuvinte } \\
\text { însușite }\end{array}$ & $\begin{array}{l}\text { Cuvinte } \\
\text { în curs } \\
\text { de } \\
\text { modelare }\end{array}$ & Observații \\
\hline
\end{tabular}

Tab. 4 Model de tabel privind profilul de achiziție a cuvintelor pentru $T^{50}$

Analizând profilurile de achiziție a cuvintelor a fiecărui copil și observând datele din tabel, se poate spune că aceștia reușeșc să își însușească între 70 și $90 \%$ din cuvintele parcurse.

\begin{tabular}{llllll}
\hline \hline N & Numel & Num & Num & Numă & Proce \\
r. & e și & ăr de & ăr de & r de & ntaj \\
\hline
\end{tabular}

\begin{tabular}{llllll}
\hline \hline $\begin{array}{l}\text { cr } \\
\text { t. }\end{array}$ & $\begin{array}{l}\text { prenu } \\
\text { mele }\end{array}$ & $\begin{array}{l}\text { cuvin } \\
\text { te } \\
\text { parcu } \\
\text { rse }\end{array}$ & $\begin{array}{l}\text { cuvin } \\
\text { învăț } \\
\text { ate }\end{array}$ & $\begin{array}{l}\text { cuvint } \\
\text { e în } \\
\text { curs } \\
\text { de } \\
\text { model } \\
\text { are }\end{array}$ \\
& & & & & \\
\hline 1. & B.A.A. & 35 & 29 & 6 & $\begin{array}{l}82,85 \\
\%\end{array}$ \\
\hline 2. & V.L. & 35 & 27 & 8 & $\begin{array}{l}77,14 \\
\%\end{array}$ \\
\hline 3. & L.A. & 30 & 21 & 9 & $70 \%$ \\
\hline 4. & B.B.I. & 30 & 27 & 3 & $90 \%$ \\
\hline 5. & V.R. & 30 & 25 & 5 & $\begin{array}{l}83,33 \\
\%\end{array}$ \\
\hline \hline
\end{tabular}

Tab.5 Rezultate obținute la $T^{50}$

Ritmul de achiziție este lent, dar cu toate acestea procentul de însușire a cuvintelor din listă este destul de ridicat. Se mențin însă o parte din tulburările de pronunție marcate de omisiuni, înlocuiri sau dificultăți de pronunție a grupurilor consonantice Cea mai bună evoluție se observă la copiii cu dizabilitate intelectuală ușoară, deși procentele nu sunt cu mult mai mari față de ceilalți. Acest lucru se poate datora și faptului că în alegerea cuvintelor s-a ținut cont de particularitățile fiecărui copil în parte.

Pentru îmbunătățirea capacității de procesare fonologică a fost elaborat un set de exerciții ce urmărește formarea abilităților de manipulare a fonemelor în cadrul cuvântului și formarea capacității de analiză și sinteză fonetică la nivelul silabei și cuvântului. Exercițiile au fost adaptate după un set de itemi care testau abilitățile lingvistice ale elevilor preșcolari din Norvegia în cadrul unui studiu desfășurat de S.A.H. Lyster, A. O. Lerva, și C. Hulme (2016). Cele mai solicitante activități din programul de conștientizare fonologică au fost introduse cu atenție la jumătatea ședinței și au implicat identificarea fonemelor , 
numărarea fonemelor, identificarea sunetului initial, combinarea fonemelor numărarea fonemelor eliminarea fonemelor inițiale. S-au efectuat în completare exerciții de despărțire în silabe, cu numărarea acestora, exerciții de combinare a silabelor în cuvinte și a cuvintelor în propoziție.

Observațiile făcute pe parcursul întâlnirilor privind modul și capacitatea de realizare a sarcinilor din programul propus, relevă faptul că acești copii întâmpină dificultăți în primul rând în ce privesc cerințele și înțelegerea sarcinilor de lucru. A fost nevoie de explicații suplimentare în ce privește modul de desfășurare a sarcinii. S-a observat, de asemenea, dificultăți la sarcinile de eliminare a fonemelor inițiale, copiii reușind cu greu să identifice imaginea corespunzătoare cuvântului rămas în urma eliminării primului sunet. La sarcinile de numărare, copiii s-au descurcat puțin mai bine, mai ales că, cuvintele nu au avut o lungime foarte mare. La exercițiile privind identificarea sunetului inițial, capacitățile de realizare a sarcinilor au fost diferite la fiecare copil.

Pentru exercițiile de despărțire în silabe a cuvintelor, au fost utilizate mai întâi cuvinte simple, bisilabice astfel încât reușita și înțelegerea sarcinii să fie destul de bună. S-a trecut apoi și la cuvinte monosilabice sau cu mai multe silabe. Exercițiile au fost desfășurate atât oral, însoțite de bătăi din palme cât și exerciții pe suport hârtie cu cuvinte însoțite de imaginea corespunzătoare și care trebuiau despărțite în silabe având și sarcina de trasare sau încercuire a numărului de silabe corespunzător. Pe parcursul activităților s-a observat că reușita sarcinii este mai mare în cazul cuvintelor bisilabice sau trisilabice în timp ce la cuvintele monosilabice sau cu mai multe silabe performanțele sunt mai scăzute.

Pentru dezvoltarea competențelor morfologice a fost elaborat un set de exerciții care a urmărit în principal dezvoltarea următoarelor categorii morfologice: substantiv număr (sg./pl.); pronume gen/ număr; numeral cardinal; numeral ordinal; prepoziţii simple. În alegerea materialului lingvistic s-a urmărit introducerea cuvintelor nou învățate prin tehnica $\mathrm{T}^{50}$. S-au folosit imagini însoțite de cerința de a identifica imaginea corespunzătoare enunțului, cum ar fi: ,Leul este în cușcă.”; ,În coș sunt mere.” ; „,Trei copii se joacă.”, „, Al treilea balon este albastru.", Ei aleargă.; , , Ochelarii sunt pe carte."

Alte activități, menite să vină în sprijinul învățării, au fost jocuri de genul ,, Eu spun una, tu spui mai multe" sau găsirea unui adjectiv potrivit pentru un substantiv sau verb dat. De asemenea, copiii au fost implicați în diverse sarcini și activități pentru însușirea conceptului de numerație și de recunoaștere a numeralelor ordinale. Aceste sarcini s-au dovedit a fi destul de dificile pentru copii, fiind însoțite de multe explicații și făcându-se paralele la alte exemple care vizau obiectele familiare sau din jurul copilului pentru a putea fi înțeleasă sarcina. În acest sens au fost folosite materiale concrete pentru a exemplifica și a înțelege numărul sau ordinea. Se mențin însă dificultăți la următoarele categorii: verb- în special modul verbului, adjectiv-grade de comparație, 
adeverbe, locuțiuni adverbiale, prepoziții compuse, morfeme suprasegmentaele, morfeme prin care se materializează categoria animat/inanimat.

Concluzionând cele de mai sus, putem afirma că la acești copii capacitatea de asimilare a cuvintelor în vocabular prin Tehnica listei celor 50 de cuvinte $-\mathrm{T}^{50}$ se manifestă în limite acceptabile, majoritatea copiilor reușind să își însușească o bună parte din cuvintele parcurse. De asemenea, o parte din aceste cuvinte au fost transferate din vocabularul pasiv în cel activ prin formularea de enunțuri, realizându-se astfel extinderea semnificației și sensului cuvântului în situații de vorbire, creând premisele extinderii și perfecționării lexicului. Putem astfel afirma că se verifică una din ipotezele noastre, cum că există o relație între utilizarea $T^{50}$ și dezvoltarea abilităților lexico-semantice.

Pe parcursul intervenției, s-a observat că acei copii care au stăpânit mai bine cuvintele nou învățate și care au reușit să le transpună mai repede în vocabularul activ, au reușit să rezolve mai bine și sarcinile care antrenează abilitățile morfologice. Aceștia au reușit să rezolve mai bine exercițiile de antrenare a acordului substantivului cu numărul sau antrenarea numeralului cardinal când sarcina era de identificare a imaginii corespunzătoare enunțului. S-a putut observa că extinderea numărului unităților lexicosemantice din vocabularul activ și pasiv și dezvoltarea abilităților de utilizare a unităților lexicosemantice, în acord cu conținuturile acestora au condus la performanțe mai bune în ce privește antrenarea componentelor morfologice.
Se poate astfel concluziona că există relații între dezvoltarea abilităților lexico-semantice și conturarea morfologică în contextul întârzierii în dezvoltare la copiii cu dizabilitate intelectuală. Totuși, nivelul de dezvoltare intelectuală influențează structura limbajului, iar utilizarea cuvintelor și a propozițiilor precum și înțelegerea semnificației lor depind de dezvoltarea cognitivă. Inteligibilitatea vorbirii rămâne încă afectată datorită erorilor articulatorii caracterizate de omisiuni, substituiri, reducerea grupurilor consonantice sau simplificarea fonemelor. De asemenea s-a observat că acești copii recurg frecvent la mecanismul imitației, la modelul de acțiune anterior, fără să supună analizei contextul prezentat. De aceea, a fost nevoie să fie adesea îndemnați și susținuți să se gândească mai întâi la conținutul sarcinii și apoi să ofere răspunsul.

\section{Concluzii}

Recuperarea întârzierii în dezvoltarea limbajului la acești copii nu este una spectaculoasă, ci se realizează cu pași mici și anevoioși iar aceasta și datorită tabloului simptomatologic pe care îl prezintă. Tulburările de atenție, tulburările emoționale, crizele de afect interferează negativ cu intervenția terapeutică. De altfel, exercițiile sunt foarte obositoare pentru copii și necesită alternarea acestora astfel încât să evităm posibile comportamente negativiste sau chiar agresive.

Până în prezent metodele și tehnicile folosite în acest studiu au adus rezultate pozitive în ceea ce privește dezvoltarea vocabularului și a laturii lexico- 
semnatice precum și dezvoltarea anumitor categorii morfemice. Totuși, pentru configurarea unei competențe de comunicare funcționale la copiii cu dizabilitate este nevoie de o perioadă de intervenție mult mai lungă, realizată în paralel cu activități de stimulare cognitivă. Chiar și în acest caz este posibil ca unii copii să râmână sub nivelul vârstei cronologice sau mentale în ceea ce privește achiziția limbajului.

\section{Bibliografie}

Avramescu, M. D., (2007). Defectologie și logopedie, Ediţia a 3-a, București: Editura Fundaţiei România de Mâine;

Bodea-Hațegan, C., (2016). LogopediaTerapia tulburărilor de limbaj. Structuri deschise, București: editura Trei;

Bodea Hațegan, C., (2014). Probă de evaluare a abilităților morfologice în limba română. Aplicații psiholingvistice, vol.III, Cluj- Napoca, edit.Argonaut, e-book;

Burlea, G., (2007). Tulburările limbajului scris-citit, București: Editura Polirom;

Law, J., Garrett, Z., Nye, C. (2005). Speech and Language Therapy Interventions for Children with Primary Speech and Language Delay or Disorder, The Campbell Collaboration; https://onlinelibrary.wiley.com/doi/p df/10.4073/csr.2005.5;

Lyster, Solveig-Alma \& Lervåg, Arne \& Hulme, Charles. (2016). Preschool morphological training produces long-term improvements in reading comprehension. Reading and Writing; https://www.ncbi.nlm.nih.gov/pmc/a rticles/PMC4875956/;

Preda, V., (2007). Elemente de psihopedagogie speciala, ClujNapoca, editura Eikon;

Slama-Cazacu, T., (1999).

Psiholingvistica, o știinţă a comunicării, București, Editura All

'.Profesor psihopedagog la Centrul S,colar pentru Educație Incluzivă „Speranța”, Zalău.

E-mail: nina mosneag@yahoo.com 